\title{
Inclusive Development in Latin America and Smallholders' Interactive Learning Spaces
}

\author{
Claudia Bastida-Mercado ${ }^{a}$, Anastacio García-Martínez ${ }^{\mathrm{b}}$, Guillermo Sanchezc
}

\begin{abstract}
Inclusive development appears as a challenge in Latin America countries after the rupture of the social inclusion as a trickle-down effect of the economic growth. Searching development with inclusion, several public policies were implemented in Latin American during the last 10 years focusing on the agri-food production. In order to assess the progress to reach such objectives, two cases are studied. Smallholder milk producers at the Loma Blanca community (Mexico) and smallholders olive producers at Aimogasta (Argentina) were considered. Interactive learning spaces were clearly identified as consequence of the linking among product, producers, and territory. The empirical evidence leaves to see a reflexive attachment between actor and activity in the both studied cases. Differences between dynamics in ILS (Interactive Learning Spaces) of each one of the studied cases were found. Nevertheless, opportunity windows are still opened in order to achieve successful interventions. Why does the small producer continue existing as such? Why do the small producers remain in small scale rather than creating scale or exiting from the market? These, and others, are trigger questions through which government and non-government organization can drive their action in the field.
\end{abstract}

\section{Keywords}

Family farming, social technology, localized agri-food systems, Mexico, Argentina

Since the failure of the economic growth as a trigger for the social inclusion-especially in Latin America (LA) countries, the inclusive development appears, which is both a challenge and a problem to be addressed. With this as a focus, several policies were implemented in LA countries considering agri-food production as a mean in order to achieve social inclusion. However, from their implementation to their success, several bottlenecks appear in the way. Learning and linkage between actors could be some of the most critical issues to be taken into account.

Two cases are analyzed in this work with the aim to discover the set of relationships involved in every experience and the way in which those ones constitute spaces for interactive learning. In the next two sections, the theoretical and methodological approaches are presented. Then the empiric evidence is presented for the two case studies. In the first instance, it presents the observations of the smallholder milk producers at the Loma Blanca community in Almoloya Juarez, Mexico State, Mexico. Then it presents the information obtained for the case of traditional olive smallholder at Aimogasta, La Rioja, Argentina. In the light of the empiric evidence, the emerging set of

\footnotetext{
aInstituto en Ciencias Agropecuarias y Rurales, Universidad Autónoma del Estado de México, Mexico

bCentro Universitario UAEM Temascaltepec, Mexico

cNational Institute of Agricultural Technology, Argentina

\section{Correspondent Author:}

Guillermo Sanchez, Coordinación Nacional de Vinculación Tecnológica, INTA, Av. Rivadavia 1479, 1er. Piso, of. B, C1033AAE, Ciudad Autónoma de Buenos Aires, Argentina
} 
relationships for each case is analyzed in the following section, in the context of the theoretical frame. The paper is closed with some final considerations.

\section{THEORETICAL FRAME}

Since the late twentieth century, accumulation processes have been developed to create competitive advantages through the incorporation of knowledge to the production of goods and services. In this way, the terms of competition between companies moved to the use of knowledge to develop learning processes and the creation of the necessary skills to achieve it (Freeman 1995; Lundvall 2009).

The empirical evidence collected more than 30 years shows that competition was not only between single actors. Globally, economies around the world are prepared to the competition through state intervention by strategic definition of specific public policies. In the literature, the Southeast Asian countries often appear as successful followers of such path. In these cases, public intervention sought to create the necessary conditions to stimulate the active participation of private actors, mainly from transnational origin (Suh 2007; Vietor and Thompson 2003). Nevertheless, the neoliberal policies implemented since the late 1980 s to the late ' 90 s (Stiglitz 2004), made those Latin American countries delay entering in that way.

Several axes cross the current problematic science, technology, and innovation in LA. Just to mention a couple of ones, on one hand, the most important is undoubtedly the Ricardian specialization, placing LA as supplier of natural resources and buyer of manufactured goods. This has created a technological path that made it difficult to turn those countries into industrialized economies. However, it is necessary to find a way to do it if these countries want to get in the way of development (Perez 2010).

A second is given by productive and social heterogeneities. The exploitation of natural resources has technological and social features specific to each one of its branches (mining, hydrocarbons, agricultural production, etc.). However, some common denominators can be identified-e.g. environmental impact, equity, and sustainability.

Without having reached an exhaustive enumeration, the above reveals a number of factors that modulate public policies, particularly in LA. To achieve the desired impact, even when those policies can be defined universally, in terms of competitiveness, value addition, new markets, exports, etc., in its territorial operational phase, they should address the mentioned specific characteristics. Those factors are modulating, downstream, the public policy from its strategic definition to reach its final impact at the level of the society. As the result, it appears the territorial reflection of the opened set of policy, technology, production, society, etc.

For a territorial approach to the problem, the learning processes appear as central elements in this dynamic. In this way, technological, productional, social, and environmental issues between others can be analyzed hollistically.

Beyond the various theoretical concepts that can be found in the literature, learning - linked to any type of production, can be described as the use of knowledge to achieve the "know what", the "know how", the "know why", and "know who". Thus, learning - by transforming new or existing knowledge, becomes more important than the mere accumulation of knowledge stock (Catulo et al. 2013; Jensen et al. 2007; Lundvall and Johnson 1994).

Considering the innovation system approach, linkage and interactive learning between actors are critical for the system dynamics. Due to the low learning culture observed in LA countries, some authors proposed the creation of Interactive Learning Spaces (ILS) (Arocena and Sutz 2010). ILS arise as opportunities for learning while actors are interacting to solve some specific problem (Arocena and Sutz 2000; 2010). In such a way, each learning space 
constitutes a block of an innovation system and often requires new organizations, institutions, and technology developed in the process. ILS can be characterized as systems if they are consolidated in the time and they are able to reproduce institutions, organization, and learning linkage (Johnson and Andersen 2012; Arocena and Sutz 2000).

The product-territory relationship is of particular importance in the development of learning processes thinking in inclusive development (Catulo et al. 2013). Localized Agri-food Systems (LAS) (Boucher 2008) is a useful approach in order to study a particular learning mode involving imbibed knowledge in products, people, and territory. Product-territory relationship arises from quality issues, related to the origin, specifics of the products, and its financial content. In that way, it is possible to observe the creation of competitive advantages by the activation of specific resources (products, know-how, networks of actors, institutions, etc.) combined with exogenous one allowing development strategies for insertion in the local production in new markets (Bastida-Mercado 2014).

The precedent concepts can be viewed from the sociological side. Thomas Hughes (1987) defined the technological systems by their objectives-e.g., to solve problems, by their components-complex, diverse, heterogeneous, and coordinated in terms of problem-solution. Consequently, the system can be composed by physical artefacts; organizations-e.g., enterprises, banks, etc.; scientific elements-e.g., books, articles, teaching and research programs, etc.; laws, regulations, patents, etc. Thus, the system objective is achieved by the interaction between its components in the way that the action of any component impacts on that of the other ones. Also, if one of the components is changed or modified, the performance of the entire system is also affected (Hughes 1987).

Through its dynamic, the technological system gives place to a process of social construction of facts and artefacts (Pinch and Bijker 1987). This construction process means that what it is understood as a problem depends on the meaning that it has for every socially relevant group. In such a way, there is not just a problem within the system but several ones with their own solution according to each socially relevant group.

From the theory presented above, it is possible to see, on one hand, that LAS can be assimilated to a technological system in terms of Hughes (1987). On the other hand, ILS are the environment-within LAS, where the process of social construction takes place (Pinch and Bijker 1987). Nevertheless, LAS and ILS are not easily distinguishable because both of them operate as a system. Also, it is not possible to say that learning processes are carried out, exclusively, within a specific portion cut down on within the LAS, the whole LAS can also be ILS. In addition, several learning processes can be established following the problem-solution identified by each one of the socially relevant groups.

\section{METHODOLOGY}

The work is based on the study of two cases: (1) the case of smallholder milk producers at the Loma Blanca community in Almoloya Juarez, Mexico State, Mexico (Bastida-Mercado 2014); and (2) the case of smallholder olive producers at Aimogasta, La Rioja, Argentina (Sanchez 2010).

Through these cases, this work pursues the aim to show two different dynamics to the inner space of ILS. Following to Yin (1994), the research was designed as a holistic analysis of multiple cases.

The empiric evidence for every case was obtained through the sequence of two steps. In the first one, secondary information was collected and analyzed in order to get an objective picture of each case. At the same time, key actors were identified in order to build subjective pictures of every case. In the second one, those already identified key actors were interviewed 
using some few trigger questions and asked them about other key actors to be included in the next interviews. In the case of milk producers, the previous methodology was accompanied, as a complement, by a survey carried out between 23 producers in order to collect quantitative data (Bastida-Mercado 2014).

The focus of this work is on the discovery of the set of relationships that emerge in every case considering its role as mediator in the dynamics of interactive learning process. With this aim, the obtained information was analyzed and interpreted following a deductive/inductive path from the theoretical perspective - as it was presented. Some sociological concepts were used in the analysis in order to highlight the social interactions that took place within such learning processes. The actor-network theory (Latour 2005), the social construction of technology (Bruun and Hukkinen 2003), and LAS (Boucher 2008) were considered. As product of such analysis, an adjacency matrix was constructed and then depicted by applying the social networks method (Hanneman and Riddle 2005), using the UCINET 6 package (Borgatti, Everett, and Freeman 2002).

\section{EMPIRIC EVIDENCE}

\section{Smallholders Milk Producers at Almoloya Juarez, Mexico State, Mexico}

Context. In Mexico, milk is produced under different systems, of which the small-scale system is not easy to place in any classification, still when this holds a significant percentage of domestic production $(25 \%$ of the herd producer and $45 \%$ of national production). This type is also considered as family system or backyard, where there is no infrastructure, records, poor technical advice, and less than 20 animals per unit of production (Espinoza-Ortega et al. 2007).

Often under the classification of small-scale production system are considered those production units with more than 20 head of cattle, leaving out the majority of producers, since in the field, most of them have fewer than 10 animals.

Dairy systems in small-scale, have been the subject of several studies (feeding, reproduction, health and management, among others) and unlike large farms under extensive management type, they have had few resources for their development. Some other features of these systems are that the cows calve every 12 to 13 months; there is reduced knowledge about feeding strategies based on their productive and reproductive status, genetic improvement by absorption or selection. Sanitary management is reduced and limited to eliminate parasites. Economic aspects have been poorly addressed, so that is not well-understood economic sustainability.

Thus, it is necessary to know the system, know the interests of producers and their problems, to act and find schemes that encourage more producers rooted in their communities to find job opportunities that will enable the development of production units and the household. Nevertheless, these are systems that have survived under adverse conditions (Arriaga et al. 1996) and are adapted according to the socio-economic demands (García-Martínez, Bernués, and Olaizola 2011).

The milk production system on a small scale in the community of Loma Blanca, at Almoloya Juarez municipality lacks a study to determine their main characteristics and their performance and productivity. In this context, it is necessary to determine the socio-economic dynamics about peasant production of milk and cheese and its impact on the local economy of the community.

The general characteristics of the production systems of corn and milk in the Toluca Valley have been described by Castelán and Mathewman (1996) as follows:

(1) They are operated by local low-income farmers, or in subsistence levels; 
(2) The main form of land property is publics or small property;

(3) The size average of the production unit is 1.5 hectares per family;

(4) The main agricultural activity is corn production;

(5) The cattle and milk production are traditional activities for producers;

(6) The herd size per household is between 1 to 15 animals, with an average of six;

(7) The milk production is highly integrated with corn production;

(8) The milk production depends on straw and stubble as animal feeding within the system;

(9) The livestock is an important form of savings, accumulation, and social status;

(10) Cattles are an important source of organic fertilizer and fuel;

(11) Due to the integration of the dairy livestock and agriculture, this is less susceptible to market fluctuations.

Almoloya de Juarez shows 3,814 milk production units from the 68,469 units of the State of Mexico [INEGI (National Institute of Statistics and Geography) 2014]. The $96.31 \%$ belongs to milk production as an economic activity of the municipality. The empiric evidence was obtained for the community of Loma Blanca in Almoloya de Juarez, State of Mexico.

In general, the studied communities have great potential to improve and expand the dairy production, since a significant portion of its population is engaged in this activity. However, it faces serious problems and constraints that significantly reduce the productivity of the system under study.

Also, cattle plays an important role for farmers because it is an alternative that has the producer to use it as generator of income and economic reserves (Arriaga et al. 1996). Thereby, they obtain a means of accumulating wealth, as well as a source of organic matter for corn crops and sometimes as work animals.
The sale of milk is an important activity for most farmers who are engaged in this activity. It is also a way to attract resources to the production system, which does not have many surpluses to market, milk being one of the main products that can be marketed.

Milk production is a profitable activity, according to the scale of production, there are several problems that can be eliminated, but mostly allow people to remain in their town developing a decent work with great benefits for Mexican society. The term "farm" is often used in LA countries, as synonyms of poverty, marginalization, and crisis. Nevertheless, it has also other nuances.

Increasing the productivity of dairy herds in the region represents a viable alternative to improve the standard of living of their owners through higher revenues from the sale of their product.

The problematic case. The problematic case under study can be addressed under three different issues as it was pointed out by Bastida-Mercado (2014). The first one is the scale as it was described previously. The second one is the traded products. These are fluid milk and cheese. Fluid milk is traded as raw milk directly to the consumer while cheese is elaborated from the raw milk in three types: Ranchero, Oaxaca, and Requeson.

The third involved issue is the group of involved actors and their relationships.

Producer is the first actor in the chain. The average age of dairy farmers is 45-79 years. Most of the farmers $(42.84 \%)$ have basic studies (primary level). One might suggest that many studies are required to venture into dairy farming in the area. So the lack of studies is not a limiting factor, since the activity involves activities in which you need to read, and know simple math operations in the production units, which facilitate the management, decision making, and situations that may develop producers even with low level of education they have. The population is practically native of the town; the average family size is five members, with sons and daughters older than 
21 years old. This represents less responsibility for the producer, because of the reduced number of people dependent on him/her.

Their main source of income comes from the primary activity combining specifically agriculture-livestock, showing the importance of milk production on a small scale in the study region. The main marketing channel is through an intermediary. Milk is offered as raw milk and such intermediary is an actor who sets the purchase price which does not vary with the time of year and ranges between USD .367 and .383 . The intermediary sells the product in the city up to USD $.689^{1}$, not to give more value added, taking the product from production unit and putting it to the door of the home. Also, between the producer and the intermediary, the commited word plays an important role, because the intermediary pays the producer every weekend in cash.

The second link in the chain is the intermediary who is the milk seller or botero. These ones are younger compared to the preceding section, the average age is 42.5 years. Most of them are from the community and have very different levels of study, $33.33 \%$ had entered trade school, 50\% completed primary level, and almost $17 \%$ completed secondary level. Its incorporation to the chain is due to an influence of the environment where they live as a survival strategy that would ensure a standard of living for themselves and their families. Moreover, this activity allows them to continue to serve independently, e.g. they are free to decide the working hours.

These actors as link in the chain have been incorporated, in average, 16 years ago. For the development of this activity, the whole family participates partially in some of the activities that demand the company (washing of containers, light truck, for example) and in some cases hires labour. Milk is collected in 40-liter cans, and meets an average volume of 235 litres per day, along a distance of about 6.5 kilometres. Then in the same car, milk is distributed and offered directly to home doors to housewives.

The broker works alone; the product is transported in containers during the marketing process. It does not use cooling system, the product is offered in its natural form as warm milk and it is sold at low volumes (per litre).

The emergence of this link, is due to the lack of vision of the producers to engage with the end user, perhaps due to that they do not perceive the domain acquired by the intermediary in the chain.

The last link in the chain is the transformer. In average, these actors are 47.8 years old with at least secondary studies. The production units are characterized by processing only the milk they produce, and in the case of the milk seller (intermediary), who also plays the role of transformer, using their milk surplus for sale to the consumer. Therefore, they do not use sophisticated material elements to develop their transformation processes, just domestic implements and the transformation process arises almost in the home kitchen. Transformer emerges from the production link as an evolution of milk producers as an alternative way to increase their income through the production of cheese (ranchero and oaxaca) products later offered in the informal market.

\section{Smallholders Olive Producers at Aimogasta, La Rioja, Argentina}

Context. In the region of the Argentinean provinces of Catamarca and La Rioja, the olive occupies $60 \%$ of the area devoted to fruit production. From the 125,000 tons produced, 75,000 are produced in the province of La Rioja and 50,000 in Catamarca. In the first, $60 \%$ of production is for canned olive and the remaining $40 \%$ is used to produce oil. In Catamarca, however, $80 \%$ of the production goes to produce oil and the remaining $20 \%$ is for canned olive [INTA (National Instiute of Agricultural Technology) 2009].

The productive structure of the region experienced significant changes driven by successive waves of 
investment in sectors promoted by fiscal measures. The production of wine and olive growing agribusiness activity characterized the region prior to the enactment of Law 22.021/79 Economic Development. Through the incentive to invest part of the income tax on agricultural and agro-industrial productions, this rule resulted in a significant expansion of the olive planted area and the start of production of jojoba. During the last decade, there has been a greater focus on olive activity leading to the expansion of primary production and manufacturing [INTA (National Instiute of Agricultural Technology) 2009; Salas and Richter 2009].

As the impact of this incentive scheme, traditional production systems-about 4,660 ha., co-habit with highly efficient integrated business systems with an area of 36,000 ha. which has not yet reached full production. The growth of the planted area was accompanied by an increase in installed capacity for production of olive oil, which according to surveys by the National Food Administration would be around 66,000 tons of oil.

In the province of La Rioja, olive planted area reached 29,500 ha., compared to 2,336 ha. in 1988, according to the national census of that year. The observed increase (more than 10 times) is due to the Economic Development Act 22021, an increase of 26,164 ha. of planted area between the last decade of the twentieth century and the first years of the new century (Ladux, personal communication, 2009).

This surface of 2,336 ha. constitutes the so-called traditional production of the province of La Rioja, from which 2,000 correspond to the variety Arauco (special for canned olives) and the rest consists of varieties for oil. The annual production of this surface is between 8,000 and 14,000 tons. This variation is given by year due to alternate bearing (alternating production) of the product, particularly for the Arauco variety, which is low in years; the decrease to values is between $40 \%$ and $50 \%$ of the peak crops. Traditional olive plantations are characterized mostly by being reduced surface: $60 \%$ of farmers cultivate an area not exceeding one ha. and $21 \%$ are located in a layer between one and five ha. [Ladux, personal communication, 2009; Salas and Richter 2009; UIA (Argentine Industry Union) 2008].

Some points can be remarked as a result of the Economic Development Act for the olive production in La Rioja. On the one hand, the planted area and the industry installed capacity have been increased and there have been interesting effects of vertical integration. On the other one, the new surface is implanted with staggered entering without reaching full production yet. This makes production data vary from year to year being necessary to estimate future values of these indicators once the olive production is in its normal production rate.

Estimations said that La Rioja olive production at the steady regime of production (in 2015) will be in the order of 200-250 thousand tons, according to the natural variations of the production cycles. According to implanted varieties, it could be estimated a $45 \%$ of olive production devoted to canned olive and about $55 \%$ to oil extraction, considering that there are dual-purpose varieties (Ladux, personal communication, 2009). Thus, once in regime, approximately, 100 thousand tons of olives for oil extraction and a similar amount for canned olive, depending on the achieved oil yield, will be available for the industrial stage. As a consequence, it should be noted that the current installed capacity for canned olive and olive oil production should be increased, approximately, twice (Ladux, personal communication, 2009).

From the previous analysis, it is expected that the olive growing in the province of La Rioja, should be transformed into a leading agribusiness in the region, with processing plants on the technological top, for both canning and oil production. The promotional scheme described before precipitated a change of scenery. In terms of economic indicators (Salas and Richter 2009), they can be considered beneficial to the 
provincial economy regarding investment, employment, and characteristics of the new companies . However, this change of scenario resulted in social tension between modern and traditional production that cannot be converted and must coexist with that.

Emerging tensions. To describe this situation, it can take for instance the traditional olive production in the Aimogasta, Department of Arauco in the province of La Rioja.

The Department of Arauco is located in north of the province of La Rioja and with Castro Barros, constituting Aimogasta Valley region, olive production being the main economic activity in the region. In the Department of Arauco, there are currently 8,000 ha. of land cultivated, equally divided between varieties for the production of table olives and olive oil. In this department, farms with less than five hectares account for $66 \%$ of the total and occupy only $20 \%$ of the total area of cultivation, involving approximately 1,500 producers (Ladux, personal communication, 2009).

These farms have a number of well-defined characteristics. In general, they have limited resources, low level of technology incorporation and work organization within the family. A producer, on average, has olive plants between 80 and 100 with low productivity that reaches $2,000 \mathrm{~kg} / \mathrm{ha}$. Also, he lives on the property and, in some cases, has fruit plants (grapes, figs, citrus), and garden for home consumption and animal growth, especially for chickens. In the management of water, flood irrigation is performed using springs spouting obtained through an 8-10 meters perforation. This irrigation system is characterized by high inefficiency and causes competition between neighbours, as a product of that inefficiency, the water runs out quickly. Once this happened, the producer performs another drill which can interfere with existing neighbour. The properties of this layer of farmers are located with a no well-defined boundary between the urban layout of the town of Aimogasta and agricultural production. Under these conditions, the urban population shares the environment and resources, especially water, with agricultural production. Also, most of the producers of this group do not have title to their olive groves since which have been received from their parents or grandparents without probate or are a part of a larger property, undivided, shared with siblings or other relatives. This represents a strong limitation to access the formal financial circuit for cultural work (harvesting, fertilizing, pruning, weeding) and/or industrialization of their productions.

Smaller producers cannot cover their needs, even with good prices. These producers have diversified occupations in order to combine their income through other jobs, in the public or private sectors. Still, these revenues allow them to cover family support but not to subsidize the expenses related to production, transforming it into a marginal activity in terms of commitment of time and resources. Moreover, this layer of farmers depends on industrialization as its production must be processed for marketing.

In contrast to the above, new farms have large amount of productive resources, high technology and work organization business type. Furthermore, vertically integrated industry with the emergence of new large scale producers broke the historic functional relationship with the traditional agricultural sector as supplier of raw material for industry. Second, the increased demand oriented to the variety Manzanilla Real was implanted with new productions contributed to depreciating the value of the Arauco variety of traditional production. Both factors put the group of small producers at a disadvantage compared to the industrial sector, to address price negotiations.

This will generate various situations faced by small producers. In the first instance, this layer of farmers has no obstacle to sell its production in large industries in the region. Since industry purchases their production with a standard price without quality requirements, producers can easily sell their 
production. This occurs while the plantations of these industries are not in regime of production. Once this has occurred, those industries go to support themselves not buying traditional production.

Given this, traditional producers adopted the strategy of adding value through self processing of its output, usually in their farms. The production is commonly sold in bulk or in drums of three or five $\mathrm{kg}$ without selection of olives. Manufacturing processes are developed with few or without sanitary controls, leading to high rates of discarding of processed product.

This strategy presents some obstacles to the growth of small producers-processors. The main obstacle appears before marketing by the ignorance of the market (standards required, actual demand of different segments, payments, etc.) and the inability to access it (essentially extra zone what is of greater profit margins).

It also has associated a serious environmental problem. Since the release of industrial waste in the yards, streets, and irrigation channels, it starts to degrade the environment. In addition, inefficient use of water for irrigation and industrial processes is compounded by an environment with low rainfall.

Waste discharges - approximately $15 \mathrm{~kg}$ per $\mathrm{kg}$ of product processed, contain caustic soda, salt, acetic acid, polyphenols, and other soluble organic solids. When these effluents are released into the producer's land, salt concentration causes the ending to leave unused parts of the grounds for cultivation. In this case, the producer and his family live with these emanations as they are domestic production units. When effluents released to the public streets generate a hazard considering the risk involved bleach and polyphenols. A similar situation occurs when the effluents are dumped into irrigation ditches.

Noting that in the region, like homemade productions before being described, agro-industrial complexes do not do any type of effluents process. It is not known as a method of treating them, so that the olive industry uses a network of evacuation to sacrifice field of the Aimogasta City.

As it was characterized, the problem of small olive producers in this region combines socio-economic and technological aspects. The emerging tension due to the coexistence with large industrial complexes vertically integrated displaces traditional supplier of industrial raw material. This tension is not caused by a large versus small competition but in the desire of the smaller to continue existing. Given this state of displacement, technological limitations emerge: low productivity of olive groves and lack of ability to industrialize its production.

Both aspects constitute an indivisible whole because the technological limitations arise from a failure to adopt problem that has its roots also in social and economic issues. For example, the incorporation of technology would allow raising productivity. Nevertheless, its success is conditioned by its context of adoption. At the same time, this will constrain the profit of the farm. The low prices that farmers received for their olives in recent years have led to a low rate of adoption of technology situation, in turn, generates low returns.

The network as problem solution. Since the mid-90s, the existence of the studied problem has caused a number of connections between actors in the region, linked to the traditional production, resulting in a network where producers, and provincial governments, and institutions of science and technology - mainly the National Institute of Agricultural Technolgy (INTA according to its Spanish name) and to a lesser extent Regional Center of Scientific Research and Technology Trasfer (CRILAR according to its Spanish name), are involved.

In this network, the knowledge associated with the production flows through Rural Extension Agency (AER), Aimogasta, under the Agricultural Experimental Station (EEA), INTA, La Rioja. In this way, they are addressed the technological aspects related to pruning, watering, fertilizing, sanitary 
management, varietal uniformity, graft and harvest, and postharvest handling. Knowledge is generated in regional projects, by the Regional Centre Catamarca-La Rioja of INTA and its dependent units (EEAs and AERs) and national projects under the National Fruit Program, Minifundios Program, and the Food Technology Strategic Area, all of them belong to INTA and are granted through INTA budget.

The conformation of this network plays an important role in the connections between producers. The emergence of crisis situations such as the threat of exclusion by a new production model is a strong incentive to make connections in the stratum of producers being studied. So organizations, for example, carry out the voice of these producers to sector areas of discussion as the provincial olive tables or seek to achieve scale industrialization and commercialization of its products. Nevertheless, at the same time, it emerges negative incentives like history and the bad cooperative experiences of the past.

In this way, actors like INTA should address the events facing network connection and disconnection and municipal and provincial agencies to achieve successful knowledge flowing into it.

In this direction, all actions taken by the public sector (AER Aimogasta, municipal and provincial governments, etc.) are focused on promoting producer organizations and strengthening existing ones. The formulated projects include activities that promote intervention through such organizations through the development of workshops and demonstration activities that encourage producers to organize for better results in the use of their resources. Irrigation consortium, for example, associated with the use of water from a particular source, is an area of interaction between a small number of producers sharing environment of water resources. To the extent that this experience is positive in terms of equity in resource availability, consensus and harmony in relationships can act as a trigger for a future organization for other purposes.
Provincial Olive Tables have also promoted the partnership between producers through an evolutionary process. The Ministry of Agriculture of the province was encouraging the participation of traditional producers, first, through associations and then through association of associations. All these actions have led to currently existence of four associations of producers.

In the Department of Arauco, it is the Association Aimoarauco Traditional Olive Producers. This is a partnership between producers which can be considered successful to the extent that it has organized its partners in various fields. The association has 30 members who have farms in the towns of Arauco, Udpinango, and Aimogasta, all in the Department of Arauco. Next to INTA and the Secretary of Agriculture of the province participating in various sanitary campaign, is part of the National Forum of Family Farming; promotion of the olive-growing activity is part of the debate in the preparation of the Olive Strategic Plan of La Rioja, which assists in training conducted by INTA and the Provincial Agriculture Secretary facilitating farms for testing, crop management, and pest control, generating a field of ongoing debate on the olive problem in its various aspects, and others.

More recently, it has promoted the integration of its primary production associated with the industrialization of raw materials as a way of addressing the environmental problem mentioned above. Aimoarauco has a processing plant for the production of canned olives that has developed through the Small Donation Program (SDP) - PNUD program of the United Nations, in collaboration with the Ministry of Agriculture of the province of La Rioja. The project was intended setting of the environmental problems caused by processing raw material at home as a means to eliminate or reduce it. The processing plant was built with a total contribution of approximately USD $20,000^{2}$, divided equally between the contribution of the SDP and the 
local contribution of the provincial Department of Agriculture. This plant, built on a site provided by one of the partners, has a barn, swimming processing, and effluent discharge channels in the fields of sacrifice. With this infrastructure, the plant has a processing capacity of $180,000 \mathrm{~kg}$ of olives produced by Aimoarauco partners. The plant has no permanent staff because the producers themselves, after harvest, develop processing with the assistance of Aimogasta AER staff from INTA. This occurs at the beginning of the process (filling pools) and along the periodic inspections necessary once filled pools. The raw material enters the plant identified with the producer's name, and is kept until they plant out of the finished product. Thus, the producer owns its production-the raw material and finished product. Overall, the finished product is sold in bulk to the fractionation of pools extracting processing by the buyer. Sometimes it is sold in containers of five $\mathrm{kg}$.

The Association has raised some medium-term milestones. Firstly, bringing facilities to achieve sanitary registration for packaging and marketing of a product with its own brand. Secondly, the incorporation of selection and boning machinery that would ensure product quality standards required by the market, diversifies their offer and achieves consistent quality in production.

\section{THE OBSERVED SET OF RELATIONSHIPS AS LEARNING SPACES}

The empiric evidence presented above brings to the sociograms of Figures 1 and 2 built using the social network method (Hanneman and Riddle 2005).

In order to proceed to such analysis, in the first place, it identified the actors conforming socially relevant groups (SRG), their relationships (connections between SRG), and the motive that gives place to every connection. This analysis allows to know how the system is nucleated around the problem-solution given place to the social construction of technology (Pinch and Bijker 1987; Hughes 1987). Methodologically, this motive is that what is interpreted as the social fluid in terms of the Actor-Network Theory (Latour 2005) flowing through the connections. In addition, it is assumed that every connection is not necessarily reciprocal. This means that the connections between SRG could be directed indicating that the flux is only in one precise direction. In Figures 1 and 2, this is marked with an arrow connecting SRG where a double arrow shows a reciprocal connection. In those figures, the motive of every connection (problem-solution linkage) or every group of connections is indicated closing them in a circle.

Figure 1 shows the set of relationships emerging for the case of milk small producers in the Loma Blanca community, at Almoloya de Juarez, Mexico State, Mexico. In this case, seven SRG were identified: producers; milk sellers; transformers; consumers; federal government; state government; and local government.

Firstly, inside the SRG producers, horizontal relationships between producer-producer are found. Even though producers are mainly individualist, it is found certain social capital, expressed as a sense of collaboration to lend or to borrow stallion, information exchange, and other agricultural implements and livestock. Community proximity results in a feeling of brotherhood belonging to the same community. In Figure 1, this is represented by an open triangle crossed by lines denoting connections inside of it.

Secondly, it appears the relationship between producer-milk sellers (intermediaries). This one lies in the buying of raw milk from the production units. On average, each purchase by the intermediary is 235 litres of milk daily, paying an average price of USD .367. The way how intermediary and producer are related, is through an established verbally contract assuring the daily supply of milk and hence the market. Payment is made every eight days and is given in cash. 


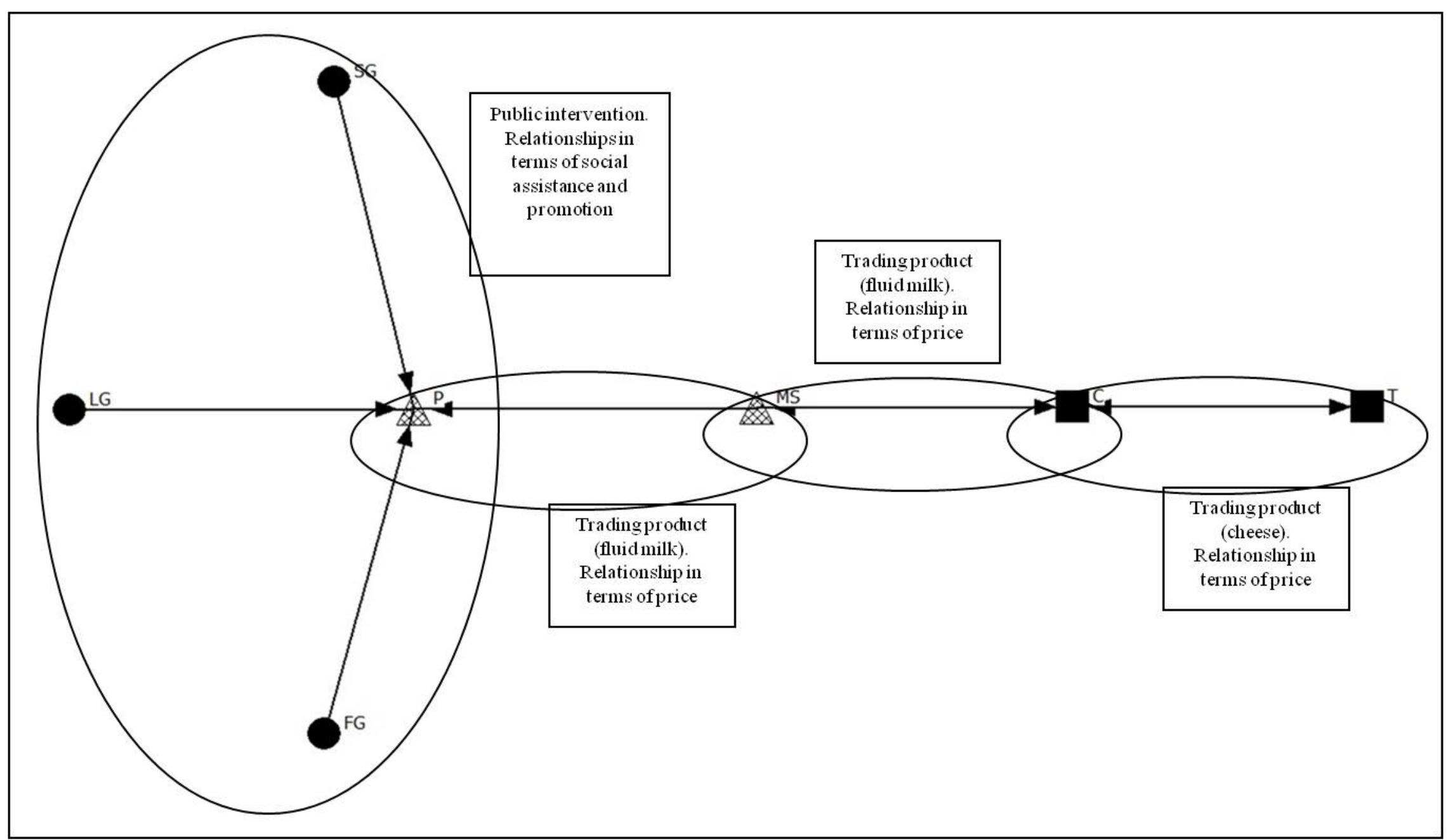

Figure 1. Set of Relationships Observed in the Case of Small Production of Milk in the Loma Blanca Community at Almoloya Juarez, Mexico State, Mexico.

Notes: Socially relevant groups: P: Producers; MS: Milk Sellers (intermediaries); T: Transformers; C: Consumers; FG: Federal Government; SG: State Government; LG: Local Government. Group of actors with horizontal connections, even weak; elaboration using UCINET 6 (Borgati et al. 2002). 


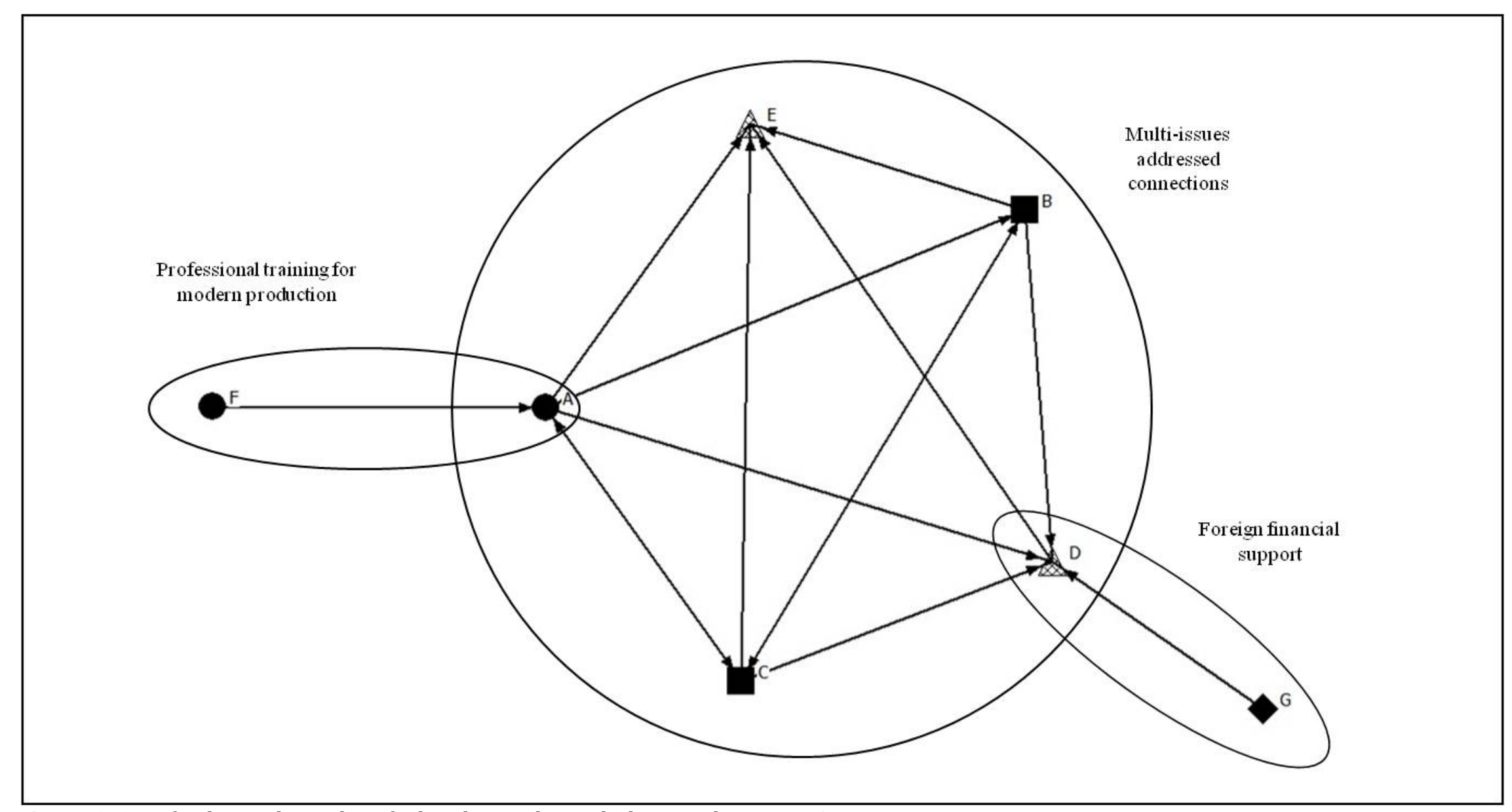

Figure 2. Set of Relationships Identified in the Traditional Olive Production at Aimogasta, La Rioja.

Notes: Socially relevant groups: A: INTA; B: La Rioja Government; C: Aimogasta Government; D: Aimoarauco Association; E: Other traditional producers; F: CRILAR-CONICET; G: Small donations program-PNUD. Group of actors with horizontal connections; Government;

Government; foreign financial support from international organization. Source: Authors' elaboration using UCINET 6 (Borgatti et al. 2002). 
Thirdly, it appears the relationship between intermediary - intermediary. These are also horizontal relationships inside the SRG milk sellers. The individualist behaviour viewed in the producers is reproduced here. However, if any of the intermediaries requires a larger amount of product, there is the possibility that other milk seller compensates and/or markets the product. As in the first case, this is represented in Figure 1 by an open triangle crossed by lines denoting connections inside of it.

The relationship between intermediary - transformer does not exist. Transformers get the raw material directly from the producers or produce it themselves. Nevertheless, some milk sellers act as transformers when it has abundance of milk that is not sold to the consumer.

The transformer link also dominates the individualism, just connections with friends and family of the same activity that is found. In the most of the cases, competition is the prevailing relationships between people engaged in the same activity without any kinds of cooperation.

In the intermediary-consumer relationship, the first one identifies the colonies where raw milk consumption is known by itself or by reference of another seller. The milk seller goes home by home offering his product. In the beginning of the relationship, it is shown itself as the best option, gives affordable prices and takes care of the product quality; also ensures milk supply according to the needs and consumer purchase frequency because on average this buys only 2-3 times a week. The milk sellers have their own vehicle to transport milk in cans and a means to dispense it. On average, the expense in gas is about USD 13.925 a day, which depends mainly on the volume of milk to be distributed, and the route to go, which is designed so as to reduce the time between delivery.

The relationships with public organisms are expressed through connection of producers with federal, state, and municipal government. In the first one, the Secretary of Agricultural, Livestock, Rural Development, Fishery and Food-SAGARPA, and the Secretary for Social Development-SEDESOL, can be mentioned. Whereas the state government links itself with the producers through the Secretary for Agricultural Development-SEDAGRO, the city government has community delegations.

The federal government also acts to regulate the milk quality through the Incentive to the Livestock Productivity Program-PROGAN. This program stimulates the productivity improvement and the technology adoption. In 2013, this program increased its coverage to the bovine livestock for beef and double purpose production in grass system, bovine milk production in family system, and ovine, goat, and honey production.

Figure 2 shows the diagram of relationships that emerge from the information presented for the case olive traditional production at Aimogasta, La Rioja, Argentina. Dots in the figure depicted the SRG indentified in this case.

The emerging tension in the traditional olive production in the province of La Rioja, Argentina, appears from the Economic Development established by Law 22.021. Product of tax incentives, the production sector of the province has received a considerable amount of investment. This has resulted not only in an increase in olive production but also in improving the quality of manufactured products and technology applied to production with the consequent access to markets with higher purchasing power. At the same time, it changed the type of companies operating in the production being most dynamic and efficient, with investors groups not linked to this production in their origin.

As a contrast, this production, which is called "modern", coexists with the traditional olive production. With a totally different production profile, traditional production must face a reality with complex nuances. This leads to a plot where actors of various kinds are involved, through which traditional 
production faces reality.

It is clear from the obtained information that such nuances come to the surface as bottle necks related to technology, production, or marketing. However, the roots are idiosyncratic factors that establish several types of constraints to the system in order to find the right solutions to the surface manifestations of problems.

Such factors arise primarily from the history of relations between producers and negative experiences from the past. These factors stimulate individualistic behaviours against new collective experiences that end up hurting the individuals themselves. A producer acting individually, it is isolated in a context of scarce resources, limiting its ability to the technology adoption and thus limiting the improvement of the sales conditions of its production. In this way, the network has allowed the flux of knowledge related to technological, productive, and organizational issues supporting their foundations on their institutions.

INTA, through Aimogasta AER, appears supporting the generation, adaptation, and dissemination of knowledge applied to production. In this aspect, it is the only institution of science and technology system in this region involved in traditional production. Through its intervention programs-Profeder, Territories, etc., it also appears as a reference to organizational support.

Promoting productive institutions in this group is given through various actions taken by the public sector. In addition to the aforementioned actions of INTA, it appears the municipal government through its Production Secretary and the provincial government through the Ministry of Agriculture. Generally, incentives to the association between producers are given indirectly by promoting their participation in horizontal areas, such as olive tables of discussions, through their organizations or providing support for production. In this latter sense acts, for example, the government of Arauco city recovered an old olive oil factory and provided staff in order to support producer organizations with the infrastructure for their production process.

Such set of relationships gives place to the pattern presented in Figure 2. As it can be seen in the figure, there is a network core with a high density of connections which are multi issues addressed. Inside this core, there are nodes (open triangle crossed by lines) representing group of actors with strong inner interactions. In Figure 2, two actors from outside the network are presented. On one hand, the Small Donations Program from PNUD contributed to giving financial support. On the other one, CRILAR-CONICET; this is a federal science and technology institution different from INTA that is present in the region nevertheless its connection is not with this network but professional training in the context of modern production. This actor is presented in this figure in order to show the existence in the region of a science and technology institution different from INTA but not involved in the studied problem.

\section{DISCUSSIONS}

Both of the cases presented above take account about the extremely importance of interactions in order to learn for overpassing bottle necks in the special case of low-tech productions. Bringing here the former discussion about inclusion-exclusion tension and inclusive development, Johnson and Andersen (2012, Ch. 7) called to go beyond innovation for the poor-intended as a combination of redistribution action and passive participation of involved actors, reaching the innovation by the poor, i.e. with the active participation of the whole involved actors.

Those authors denote the interactive nature of the actions and remark the important role played by indigenous and traditional knowledge supporting the building capabilities process (Johnson and Andersen 2012). Exactly, this issue is addressed by the concept of LAS. This concept arose during the 90 s in order to attack the exclusion process emerging in Latin 
America as a consequence of the economic policy dictated by Washington Consensus (Muchnik 2006; Stiglitz 2004). Researchers in the field found that by using local technologies, they knew how the added value retained by farmers; the incomes of rural families; the offer of rural employment; and the food safety of both rural and urban populations, were improved (Muchnik 2006).

The both presented cases are based on local technology and know-how addressing impacts as were pointed out by Muchnik (2006). However, the ILS (Arocena and Sutz 2000) emerging around every studied case are radically different from each other.

In the milk small producers case, interaction looks weak. Horizontal interactions are almost absent while vertical ones are of the type producer-consumer ruled by price. Interactive learning is found only at the producer level where some horizontal interaction occurs and also some government interventions are found. According to that, it was pointed out by Johnson and Andersen (2012) that this case was still in the phase of redistribution and passive participation of involved actors. In the light of this argument, Figure 1 can be explained.

However, remitting to ILS as learning-by-solving, an opportunity window can be found to improve the public intervention (left side of Figure 1). This is due to the embryonic presence of some weak interactions (open triangles in Figure 1), it can be identified to answer some queries and then strengthen them. Why does the dairy activity persist in the area of Loma Blanca? The answer flows through three elements. The first element is the inheritance. Producers and distributors are engaged in this activity because of their parents and grandparents who were farmers and they continue the tradition still when they did not learn other activity in the childhood. The second element is because it is the predominant activity in the region. Producers are followers, seeing that this activity shows profit, and they possess the necessary knowledge of the know-how to handle this type of production systems. The third element is for pleasure and as subsistence means. Producers, transformers, and distributors are on this activity because they believe that the activity gives them satisfaction or well-being and acts as means to obtain resources to survive. The three elements motivate the continuity of dairy farming in the region, inside the territory, they are endogenous elements, which suggests a reflexive attachment between actor and activity.

The case of olive traditional producers can be clearly viewed as an interactive learning space highly dynamic, where the combination of innovation for and by the poor is achieved.

From the description of Figure 2, it can be understood that in this case, the ILS seem to be consolidated where the active participation of producers is sheared with the intervention of government, non-government, and science and technology organizations (network core in Figure 2). Inside such core, the connections between the actors are given by the flow of a substance of complex features. It combines standard knowledge associated with production, processing, and organization, combining learning-by-solving (Arocena and Sutz 2010) processes-e.g. "know what", "know how", and "know why". One feature that is particular to this network is that both learning processes and knowledge flow are in all directions because actor who learns about something can provide knowledge about another aspect. For example, producers must learn about the environmental management of the industrialization of raw material at the same time they have the knowledge on how to carry out that industrial processing. Similarly, they have embedded their own idiosyncrasies. Thus, they know what the best incentives are for a successful intervention of public actors-INTA, local and province government, and promoting association.

At this point, it is important to remark the role of donor organizations as it is described by Johnson and Andersen (2012). By comparing the studied cases, it 
can be viewed differences in the number-or the density, of such sort of institution. While the Mexican case only appears government organizations, the Argentinean one appears government and non-government organization and also one international program - Small Donation Program from PNUD, UN (United Nations).

\section{CONCLUSIONS}

In the both studied cases, it can be seen the existence of a very strong link among product, producers, and territory. These connections, clearly, give place to the interactive learning space. Despite it found differences between dynamics in ILS of each one of the studied cases, opportunity windows are still opened in order to achieve successful interventions. Why does the small producer continue existing as such? Why do the small producers remain in small scale rather than creating scale or exiting from the market? These, and others, are trigger questions through which government and non-government organization can drive their action in the field.

\section{Notes}

1. Values in United State Dollars were obtained considering an average of .0765 USD per Mexican Peso according to Banco de México. Retrieved (http://www.banxico.org.mx/ portal-mercadocambiario/).

2. Using an average exchange rate, for the period, of 3.1627 local currency per United State Dollar as reported by the Central Bank of Argentine Republic. Retrieved (http://www.bcra.gov.ar/estadis/es030102.asp).

\section{References}

Arocena, R. and J. Sutz. 2000. Interactive Learning Spaces and Development Problems in Latin America. DRUID Danish Research Unit for Industrial Dynamics Working Paper 13/2000. Retrieved February 11, 2014 (http://www.druid. dk/uploads/tx_picturedb/ds2000-86.pdf).

_. 2010. "Weak Knowledge Demand in the South: Learning Divides and Innovation Policies." Science and Public Policy 37(8):571-582.
Arriaga, J. C., O. A. Espinoza, G. H. E. Rojo, M. Valdés, and P. B. Albarrán. 1996. La Producción de Leche en el Valle de Toluca. Una Respuesta al Ajuste Estructural en el Campo Mexicano (Milk Production in the Toluca Valley. An Answer to the Structural Adjustment in the Mexican Farm). Mimeo, Toluca, Estado de México, México.

Bastida-Mercado, C. 2014. "Caracterización del Sistema de Producción de Leche en la Comunidad de Loma Blanca, Almoloya de Juárez, Estado de México" (Characterization of the Milk Production System in the Community of Loma Blanca, Almoloya de Juárez, Estado de México). Master thesis in Rural Agroindustry, Territorial Development and Rural Turism. Universidad Autónoma del Estado de México, Toluca, Estado de México, México.

Borgatti, S. P., M. G. Everett, and L. C. Freeman. 2002. Ucinet for Windows: Software for Social Network Analysis. Harvard, MA: Analytic Technologies.

Boucher, F. 2008. "La Leche Como Instrumento de Desarrollo Territorial de los Pequeños Productores Para Acceder a Nuevos Mercados" (The Milk as a Tool for the Territorial Devolpment of Small Producers in Order to Reach New Markets). En IICA, De la Leche al Queso, Queserías Rurales en América (In IICA, From Milk to Cheese. Rural Cheese Factories in América). México, D.F.: IICA-Miguel Ángel Porrúa.

Bruun, H. and J. Hukkinen. 2003. "Crossing Boundaries: An Integrative Framework for Studying Technological Change." Social Studies of Science 33:95.

Castelán, O. O. and R. Mathewman. 1996. "Situación y Perspectiva de la Industria Lechera en México, con Énfasis en Lechería en Pequeña Escala" (Situation and Perspective of the Dairy Industry in Mexico With Emphasis in Milk Production at Small Scale). En Estrategias Para el Mejoramiento de los Sistemas de Producción de Leche en Pequeña Escala (In Strategies for the Improvement of Small Scale Milk Production Systems). UAEM/CICA. Toluca, México.

Catulo, J. C., H. G. Varela, C. Alemany, G. Torres, F. Chavez, L. Brunale, ... H. Saravia. 2013. The Role of Rural Extension in Innovation Management. Programa Cooperativo Para el Desarrollo Tecnológico Agroalimentario y Agroindustrial del Cono Sur (Cooperative Program for the Agri-food and Agroindustry Technological Development) (PROCISUR), Montevideo, Uruguay. Retrieved January 20, 2014 (http://www.procisur. org.uy/images/M_images/libro-docextensin-espaol.pdf).

Espinoza-Ortega, A., E. Espinosa-Ayala, J. Bastida-López, T. Castañeda-Martínez, and C. M. Arriaga-Jordán. 2007. "Small-Scale Dairy Farming in the Highlands of Central Mexico: Technical, Economic and Social Aspect and Their Impact on Poverty." Experimental Agriculture 43:241-256.

Freeman, C. 1995. "The 'National System of Innovation' in 
Historical Perspective (Part of a: Special Issue on Technology and Innovations)." Cambridge Journal of Economics 19:5-24.

García-Martínez, A., A. Bernués, and A. Olaizola. 2011. "Simulation of Mountain Cattle Farming System Changes Under Diverse Agricultural Policies and Off-farm Labour Scenarios." Livestock Science 137:73-86.

Hanneman, R. A. and M. Riddle. 2005. Introduction to Social Network Methods. Riverside, CA: University of California. Riverside, California, EE. UU. (Published in digital form at http://faculty.ucr.edu/ hanneman/).

Hughes, T. P. 1987. "The Evolution of Large Technological Systems." In The Social Construction of Technological Systems. New Directions in the Sociology and History of Technology, edited by W. E. Bijker, T. P. Hughes, and T. J. Pinch. Cambrdge: The MIT Press.

INEGI (National Institute of Statistics and Geography). 2014. Agricultural, Cattle and Forest Census 2007. Retrieved February 19, $2014 \quad$ (http://www.inegi.org.mx/est/ contenidos/proyectos/agro/default.aspx).

INTA (National Instiute of Agricultural Technology). 2009. Plan Tecnológico Regional. Centro Regional Catamarca-La Rioja (Regional Technological Plan. Regional Centre Catamarca-La Rioja). Retrieved (http://www.inta.gov.ar).

Jensen, M. B., B. Johnson, E. Lorenz, and B. A. Lundvall. 2007. "Forms of Knowledge and Modes of Innovation." Research Policy 36:680-693.

Johnson, B. and A. D. Andersen. 2012. Learning, Innovation and Inclusive Development. Aalborg, Denmark: Aalborg University Press.

Latour, B. 2005. Reassembling the Social-An Introduction to Actor-Network Theory. New York, USA: Oxford University Press.

Lundvall, B. 2009. "Introduction." In National System of Innovation (Ch. 1), edited by B. Lundval. San Martín, Buenos Aires, Argentina: UNSAM EDITA. Pp. 11-30.

Lundvall, B.-A. and B. Johnson, 1994. "The Learning Economy." Industry and Innovation 1(2):23-42.

Muchnik, J. 2006. "Sistemas Agroalimentarios Localizados: Evolución del Concepto y Diversidad de Situaciones" (Localized Agri-food Systems: Concept Evolution and Diversity of Situations). III Congreso Internacional de la Red SIAL. "Sistemas Agroalimentarios Locales." Alimentación y Territorios. “ALTER 2006.” Baeza (Jaén), España, 18-21 de Octubre 2006 (Presented at III International Congress of the SIAL Network. "Localized Agri-food System." Feeding and Territory. ALTER 2006. Baeza, Jaén, Spain, October 18-21, 2006).

Nelson, R. 2007. "Economic Development From the Perspective of Evolutionary Economic Theory. The Global
Network for Economics of Learning, Innovation, and Competence Building System (GLOBELICS)." Working Papers Series No. 2007-02. Retrieved November 25, 2014 (http://dcsh.xoc.uam.mx/eii/globelicswp/wpg0702.pdf).

Perez, C. 2010. "Technological Dynamism and Social Inclusion in Latin America: A Resource-Based Production Development Strategy." CEPAL Review 100:121-141. Retrieved November 25, 2014 (http://www.eclac.cl/ cgi-bin/getProd.asp? xml=/revista/noticias/articuloCEPAL/2 /40532/P40532.xml\&xsl=/revista/tpl-i/p39f.xsl\&base=/revi sta/tpl-i/top-bottom.xsl).

Pinch, T. J. and W. E. Bijker. 1987. "The Social Construction of Facts and Artifacts: Or How the Sociology of Science and the Sociology of Technology Might Benefit Each Other." In The Social Construction of Technological Systems. New Directions in the Sociology and History of Technology, edited by W. E. Bijker, T. P. Hughes, and T. J. Pinch. Cambrdge: The MIT Press.

Salas, P. I. and L. Richter. 2009. Caracterización y Evaluación de Tramas Productivas Estratégicas y Validación en el Sector Olivícola. Informe de Avance (Characterization and Evaluation of Strategic Productive Networks and Its Validation in the Olive Sector. Advance Report). Ministerio de Economía y Producción de la Nación, Programa de fortalecimiento institucional productivo y de gestión fiscal provincial. PROFIP BID 1588/OC-AR. Provincia: La Rioja. Proyecto de fortalecimiento institucional del ministerio de Producción y Desarrollo Local (National Ministry of Economy and Production. Program of Institutional, Productvie and Province Fiscal Management Strengthening. PROFIP BID 1588/OC-AR. Provincia: La Rioja). Buenos Aires, 2009.

Sanchez, G. 2010. "Insertion of INTA in Innovation Networks of Different Sub National Agri-food Production.” Master thesis, Universidad Nacional de Gral, Sarmiento, Los Polvorines, Buenos Aires, Argentina. Retrieved June 30, 2010 (http://www.ungs.edu.ar/areas/pos_tesis/75/insercion del-inta-en-redes-de-innovacion-de-diferentes-tramas-agroa limentarias-regionales.html).

Sen, A. and B. Kliksberg. 2009. Primero la Gente. Una Mirada Desde la Ética del Desarrollo a los Principales Problemas del Mundo Globalizado (First the People. A Look From the Ethics of the Development to the Main Problems of a Globalized World). Buenos Aires, Argentina: Temas Grupo Editorial SRL.

Stiglitz, J. E. 2004. The Post-Washington Consensus. The Initiative for Policy Dialogue. New York, USA: Columbia University. Retrieved November 25, 2014 (http://policy dialogue.org/files/events/Stiglitz_Post_Washington_Consen sus_Paper.pdf).

Suh, J. 2007. “Overview of Korea's Development Process Until 
1997.” In Korea as a Knowledge Economy: Evolutionary Process and Lessons Learned, edited by Suh and Chen. Washington, USA: The International Bank of Reconstruction and Development.

UIA (Argentine Industry Union). 2008. Debilidades y Desafios Tecnoló Gicos del Sector Productivo (Weakeness and Technological Challenges of the Productive Sector). Unión Industrial Argentina, Agencia Nacional de Promoción Científica y Tecnológica, Programa Nacional para la Federalización de la Ciencia, la Tecnología y la Innovación, Ministerio de Ciencia, Tecnología e Innovación Productiva (Argentine Insdustry Union, National Agency of Technological and Scientifica Promotion. National Program of Federalization of Science, Technology and Innovation. National Ministry of Science, Technology and Productive Innovation). Retrieved November 25, 2014 (http://www. uia.org.ar/fla/ debilidades2008/index.html).

Vietor, R. and E. Thompson. 2003. Singapore Inc. Boston, MA, USA: Harvard Business School.

Yin, R. 1994. Case Study Research, Design and Methods. London, UK: Sage Publication.

\section{Bios}

Claudia Bastida-Mercado, Master in rural agroindustry, territorial development, and agri-food tourism by de Autonomous University of State of Mexico, specialist in food technology, currently is an independent consultant on agribusiness; research field: localized agri-food systems.

Anastacio García-Martínez, Doctor of Science by the Faculty of Veterinary Medicine, Zaragoza University, Spain, Master of Science by the Faculty of Veterinary Medicine, National Autonomous University of Mexico, a researcher level I in the National System of Researchers (NSI) of Mexico, attached to the University Centre UAEM Temascaltepec as a teacher-researcher full time; research fields: animal production in tropical conditions, agricultural economics, and simulation models.

Guillermo Sánchez, Doctor in Physics of the National University of Rosario (Rosario, Argentina) and Master in Science, Technology and Innovation Management of National University of General Sarmiento (Buenos Aires, Argentina), researcher at the National Institute of Agricultural Technology (INTA) and the National Council of Scientific and Technique Research (CONICET), professor at the Faculty of Agronomy and Agri-food Science, Moron University, Buenos Aires, Argentina and lecturer of Research Methodology, and Technology and Food Quality in post graduated courses at Rio Cuarto National University (Cordoba, Argentina), project assessor of innovation projects of National Ministry of Science, Technology and Productive Innovation; research field: the study of learning network associated to agri-food regional innovation systems focused on the intervention public institution of science and technology. 